\title{
Application of boric acid doses in association with tannery sludge in the early development of black pepper
}

\section{Aplicação de doses de ácido bórico em associação com lodo de curtume no desenvolvimento inicial da cultura da pimenta-do-reino}

\section{Leandro Glaydson da Rocha PINHO'; Wellington Raasch PISKE²; Luciene Lignani BITENCOURT³;} Loren CHISTÉ ${ }^{\text {; }}$ Sávio da Silva BERILLI ${ }^{5}$

\author{
${ }^{1}$ Licenciado em Ciências Agrícolas, D.Sc. em Produção Vegetal, Professor do Instituto Federal do Espírito Santo, Campus \\ Itapina, leandro.pinho@ifes.edu.br. "Autor para correspondência \\ 2 Engenheiro Agrônomo, Instituto Federal do Espírito Santo, Campus Itapina, wellingtonpr19@hotmail.com \\ ${ }^{3}$ Médica Veterinária, D.Sc. em Produção Animal, Professora do Instituto Federal do Espírito Santo, Campus Itapina, \\ luciene.lignani@ifes.edu.br \\ ${ }^{4}$ Engenheira Agrônoma, MSc. em Solos e Nutrição Mineral de Plantas, Universidade Federal do Espírito Santo, Campus \\ Alegre, loren.chiste@gmail.com \\ ${ }^{5}$ Engenheiro Agrônomo, D.Sc. em Produção Vegetal, Professor do IFES, Campus Itapina, savio.berilli@ifes.edu.br
}

Recebido em: 26-11-2019; Aceito em: 24-05-2020

\begin{abstract}
Information on the effects of boron and tannery sludge application on the growth and development of black pepper is insufficient to support the recommendations of these inputs for the crop. The present experiment establishes adequate doses of boric acid in combination with the application of industrial waste from leather processing plants for the development of the black pepper cultivar 'Bragantina'. We conducted the experiment in a greenhouse at IFES - Itapina Campus, Colatina city, Espírito Santo State, Brazil. For that, we used B horizon samples of a Red-Yellow Argisol as substrate. The experimental design was completely randomized in a factorial scheme with four replicates. Treatments consisted of three boric acid doses $\left(0 ; 2 ; 4 \mathrm{mg} \mathrm{dm}^{-3}\right)$ in association with three tannery sludge doses $\left(0 ; 0.125 ; 0.250 \mathrm{dm}^{3} \mathrm{dm}^{-3}\right)$ up to the vessel volume $\left(18 \mathrm{dm}^{-3}\right)$, with 14 sampling times. We assessed the following variables: vegetative plant growth; symptoms of boron deficiency and/or toxicity; soil pH; boron content. Soil application of boric acid showed considerable results in the early development of black pepper plants; the dose with the best response was $2 \mathrm{mg} \mathrm{dm}^{-3}$. Using tannery sludge doses of 0.125 and $0.250 \mathrm{dm}^{3} \mathrm{dm}^{-3}$ in the substrate was lethal for black pepper.
\end{abstract}

Additional keywords: boron; industrial waste; nutrition; piper nigrum L.

\begin{abstract}
Resumo
As informações relacionadas aos efeitos da aplicação de lodo de curtume e boro no crescimento e desenvolvimento da pimenta-do-reino são insuficientes para dar suporte as recomendações destes insumos para o desenvolvimento desta cultura. O presente experimento objetivou estabelecer doses adequadas de ácido bórico associados a aplicação de resíduos industriais gerados pela fábrica de beneficiamento de couros. $\mathrm{O}$ experimento foi conduzido com pimenta-do-reino, cultivar 'Bragantina', em casa de vegetação localizada no IFES-Campus Itapina, cidade de Colatina-ES. Foi utilizado amostras do horizonte B de um Argissolo Vermelho-Amarelo como substrato. Utilizou-se o delineamento inteiramente casualizado, em esquema fatorial, com quatro repetições. Os tratamentos foram formados por três doses de ácido bórico $\left(0,2\right.$ e $\left.4 \mathrm{mg} \mathrm{dm}^{-3}\right)$ combinados com três doses de lodo de curtume $\left(0,0,125 \mathrm{e} 0,250 \mathrm{dm}^{3} \mathrm{dm}^{-3}\right)$ do volume do vaso $\left(18 \mathrm{dm}^{3}\right)$ e 14 épocas de amostragem. Foram avaliados 0 crescimento vegetativo das plantas, sintomas de deficiência e ou toxidez de boro, $\mathrm{pH}$ do solo e teor de boro. A aplicação de ácido bórico via solo apresentou resultados consideráveis no desenvolvimento inicial das plantas de pimenta-do-reino onde a dose de melhor resposta foi $2 \mathrm{mg} \mathrm{dm}^{-3}$ do fertilizante. O uso de lodo de curtume nas concentrações de 0,125 e $0,250 \mathrm{dm}^{3} \mathrm{dm}^{-3}$ no substrato foi letal para a cultura de pimenta-do-reino.
\end{abstract}

Palavras-chave adicionais: boro; nutrição; piper nigrum L.; resíduos industriais.

\section{Introduction}

Black pepper (Piper nigrum L.), also known as Indian pepper, is a perennial, shrubby, and vine species. It originates in tropical regions of India, and is the most common and most important spice in the world (Maistre, 1969). According to data from IBGE (2018), Brazil produced 54.4 thousand tons of black pepper in 2016. Pará State accounted for $65.80 \%$ of the production, followed by Espírito Santo, with $23.52 \%$, and Bahia, with $9 \%$. This shows that these three states concentrate the production of this crop in the country. Black pepper is a tropical plant that finds favorable conditions between latitudes $20^{\circ} \mathrm{N}$ and $20^{\circ} \mathrm{S}$ (Botelho \& Oliveira, 2009). 
The crop has a high nutritional requirement. Moreover, Brazilian producers grow black pepper in soils that are mostly of low natural fertility. This leads to the need to apply fertilizers so as to ensure vigorous growth and high yield (Botelho \& Oliveira, 2009). Inadequate fertilization of the crop, without technical criteria, can cause losses to the producer either by lower yields due to nutritional imbalances or by excessive spending on fertilizers.

Boron is present in the soil solution in the form of boric acid $\left(\mathrm{B}(\mathrm{OH})_{3}\right)$, which is highly soluble at $\mathrm{pH}$ conditions between 5.5 and 7.5. Thus, it can be easily leached in high rainfall areas (Camacho-Cristóbal et al., 2008). Its main function is as a structural component of the cell wall, acting in several important biological processes. Boron alters enzymatic systems; participates in carbohydrate translocation and metabolism; plays an important role in flowering, pollen tube growth, and phenol accumulation; acts in fruiting, in $\mathrm{N}$ metabolism, and in hormonal systems; besides influencing photosynthesis, being a fundamental microelement for early plant growth (Dechen \& Nachtigall, 2007).

Several heavy metals are essential for plants, such as copper $(\mathrm{Cu})$, zinc $(\mathrm{Zn})$, and manganese $(\mathrm{Mn})$. In turn, lead $(\mathrm{Pb})$ and chromium $(\mathrm{Cr})$ are potentially toxic for these organisms (Taiz \& Zeiger, 2004). Studies are currently addressing the use of industrial waste as an alternative means of fertilization in agriculture (Sales et al., 2018; Comério et al., 2019; Gianello et al., 2011).

Tannery sludge from leather industries is rich in important nutrients for plants, including nitrogen $(\mathrm{N})$, calcium $(\mathrm{Ca})$, magnesium $(\mathrm{Mg})$, potassium $(\mathrm{K})$, phosphorus $(P)$, and sulfur $(S)$. However, the presence of chromium $(\mathrm{Cr})$ and sodium $(\mathrm{Na})$ in its chemical composition may restrict its use in agriculture (Singh et al., 2015; Silva et al., 2010).

There is little research addressing nutrient application in black pepper or characterizing the nutritional status of plants. From an environmental point of view and due to the size of the planted area of this crop, black pepper can become a crop accessible to the application of industrial waste as a source of nutrients. However, scientific data must support this application. In this context, the present experiment establishes adequate boric acid doses in association with the application of industrial waste from leather processing plants as a source of nutrients. The study aims for better development of the crop, providing its nutrition and continuous yield improvement.

\section{Material and methods}

For the experiment, we grew the black pepper cultivar 'Bragantina' in a greenhouse at Ifes - Itapina Campus (19 $32^{\circ} 16^{\prime \prime} \mathrm{S}$ latitude and $40^{\circ} 37^{\prime} \mathrm{59}$ ' W longitude).

The experimental design was completely randomized in a factorial scheme with four replicates. Treatments consisted of three doses of boric acid $(0,2$ and $4 \mathrm{mg} \mathrm{dm}^{-3}$ ) in association with three tannery sludge doses $\left(0,0.125\right.$ and $\left.0.250 \mathrm{dm}^{3} \mathrm{dm}^{-3}\right)$. For that, we used pots with $25 \mathrm{~cm}$ diameter and $36.7 \mathrm{~cm}$ height, which we filled with $18 \mathrm{dm}^{3}$ of the substrate. We analyzed the variables throughout 14 sampling times in a total of 120 days. The first sampling occurred at planting, the second at 30 days, and the others every seven days. Spacing was $60 \mathrm{~cm}$ between rows and $50 \mathrm{~cm}$ between plants.

We used the B horizon of a Red-Yellow Argisol as substrate, whose chemical analysis showed the following results: $\mathrm{pH}=4.72 ; \mathrm{Al}=0.22 \mathrm{cmol}_{\mathrm{c}} \mathrm{dm}^{-3}$; $\mathrm{Ca}=1.43 \mathrm{cmol}_{\mathrm{c}} \mathrm{dm}^{-3} ; \mathrm{Mg}=0.90 \mathrm{cmol}_{\mathrm{c}} \mathrm{dm}^{-3}$; $\mathrm{H}+\mathrm{Al}=2.08 \mathrm{cmol}_{\mathrm{c}} \mathrm{dm}^{-3} ; \mathrm{K}=44 \mathrm{mg} \mathrm{dm}^{-3} ; \mathrm{P}=$ $4.6 \mathrm{mg} \mathrm{dm}^{-3} ; \mathrm{S}-S O_{4}=99.6 \mathrm{mg} \mathrm{dm}^{-3} ; \mathrm{B}=0.1 \mathrm{mg} \mathrm{dm}^{-3}$; $\mathrm{Cu}=0.3 \mathrm{mgdm}^{3} ; \mathrm{Fe}=26.0 \mathrm{mg} \mathrm{dm}^{-3} ; \mathrm{Mn}=4.3 \mathrm{mg} \mathrm{dm}^{-3}$; $\mathrm{Zn}=0.5 \mathrm{mg} \mathrm{dm}{ }^{-3}$; O.M. $=1.70 \mathrm{dag} \mathrm{kg}^{-1}$; P-rem = $18.5 \mathrm{mg} \mathrm{L}^{-1}$.

Chemical analysis followed the following procedures: (Al, $\mathrm{Ca}, \mathrm{Mg}-\mathrm{KCl} / \mathrm{L}$ method); $(\mathrm{H}+\mathrm{Al}-\mathrm{SMP}$ buffer solution method); (K, P, Cu, Fe, Mn, and $\mathrm{Zn}$ Melich-1 method); (S-SO $4-\mathrm{Ca}\left(\mathrm{H}_{2} \mathrm{PO}_{4}\right)_{2} 0.01 \mathrm{~mol} / \mathrm{L}$ method); ( $\mathrm{B}-0.125 \% \mathrm{BaCl}_{2} 2 \mathrm{H}_{2} \mathrm{O}$ method); (O.M. oxidation method: $\mathrm{Na}_{2} \mathrm{Cr}_{2} \mathrm{O}_{7} 2 \mathrm{H}_{2} \mathrm{O} 4 \mathrm{~mol} \mathrm{~L}^{-1}+\mathrm{H}_{2} \mathrm{SO}_{4} 10$ mol L-1); (P-rem - phosphorus in equilibrium solution method) (Embrapa, 1997; Tedesco et al., 1995; Raij et al., 2001). At sixty days before planting, we added 0.519 $\mathrm{g} \mathrm{dm}^{-3}$ calcitic limestone (PRNT $=91 \%$ ) to the soil to increase the base saturation to $75 \%$, in a mixture containing $40 \%$ of fine sand. We mixed these elements prior to their incorporation into the soil so as to ensure a homogeneous application. As the soil was very clayey, using this proportion of sand made the substrate medium texture.

The chemical analysis of the solid organic fertilizer (tannery sludge) provided by the company 'Capixaba Couros' showed the following results: total organic matter $=29.36 \%$; compostable organic matter = $11.02 \%$; organic carbon $=6.12 \% ; \mathrm{C}: \mathrm{N}$ ratio $=3: 1$; $\mathrm{N}=1.76 \% ; \mathrm{P}=0.52 \% ; \mathrm{K}=0.06 \% ; \mathrm{Ca}=22.59 \%$; $\mathrm{Mg}=1.56 \% ; \mathrm{S}=1.32 \% ; \mathrm{B}=258 \mathrm{mg} \cdot \mathrm{dm}^{-3} ; \mathrm{Na}=0.55 \%$; $\mathrm{Cr}^{3}=3.70 \%$; clayey granulometry. The analysis followed the methodology recommended by the Ministry of Agriculture, Livestock, and Supply (MAPA, 2013). We added the boric acid and tannery sludge doses to the substrate before transplanting the seedlings. We mixed the elements homogeneously, applying the mixture individually so as to ensure the exact dose for each plant and to reach the final volume of $18 \mathrm{dm}^{3}$.

At the time of planting, we removed the original substrate present in the roots of seedlings, subsequently treating these plants. Nursery 'Demuner', in São Roque do Canaã city, Espírito Santo State, provided the seedlings in excellent nutritional condition. Their average height and average number of leaves were $28.77 \mathrm{~cm}$ and 6.29 , respectively. To meet the water needs of the plants, we irrigated them every two days by adding $1.0 \mathrm{~L}$ of water per plant. After planting, we weekly assessed the following variables: vegetative plant growth, symptoms of boron deficiency and/or toxicity, and the effect of tannery sludge. 
At the end of the 14 sampling times, we analyzed soil $\mathrm{pH}$ in each treatment. Then, we cut the plants at the neck region, thus collecting whole plants, which we packed in Kraft paper bags. In the laboratory, we separated stems and leaves, cleaning them with cotton previously soaked in deionized water. We stored the material in a forced air circulation oven at $75^{\circ} \mathrm{C}$ for 48 hours.

After drying, we obtained the dry matter of stems and leaves. Subsequently, we ground the plant material in a Wiley mill with a 30-mesh sieve. We then determined boron content in the leaves and stem using the azomethine-H method (Malavolta et al., 1997).

We submitted the results to analysis of variance using the $\mathrm{R}$ program, and compared the means using the Tukey test at $5 \%$ probability.

\section{Results and discussion}

The experiment showed significant results for the effects of boric acid and tannery sludge doses and sampling times as a function of the parameters of early plant development. For the number of leaves, regardless of the boric acid doses, the treatments in which the plants received tannery sludge in the doses of 0.125 and $0.250 \mathrm{dm}^{3} \mathrm{dm}^{-3}$ showed leaf toxicity symptoms. These included yellowing of shoots; brownish spots; necrotic internerval spots; and necrosis, initially, in the leaf blade. This led to gradual and total leaf fall in the first two months (Figure 1).

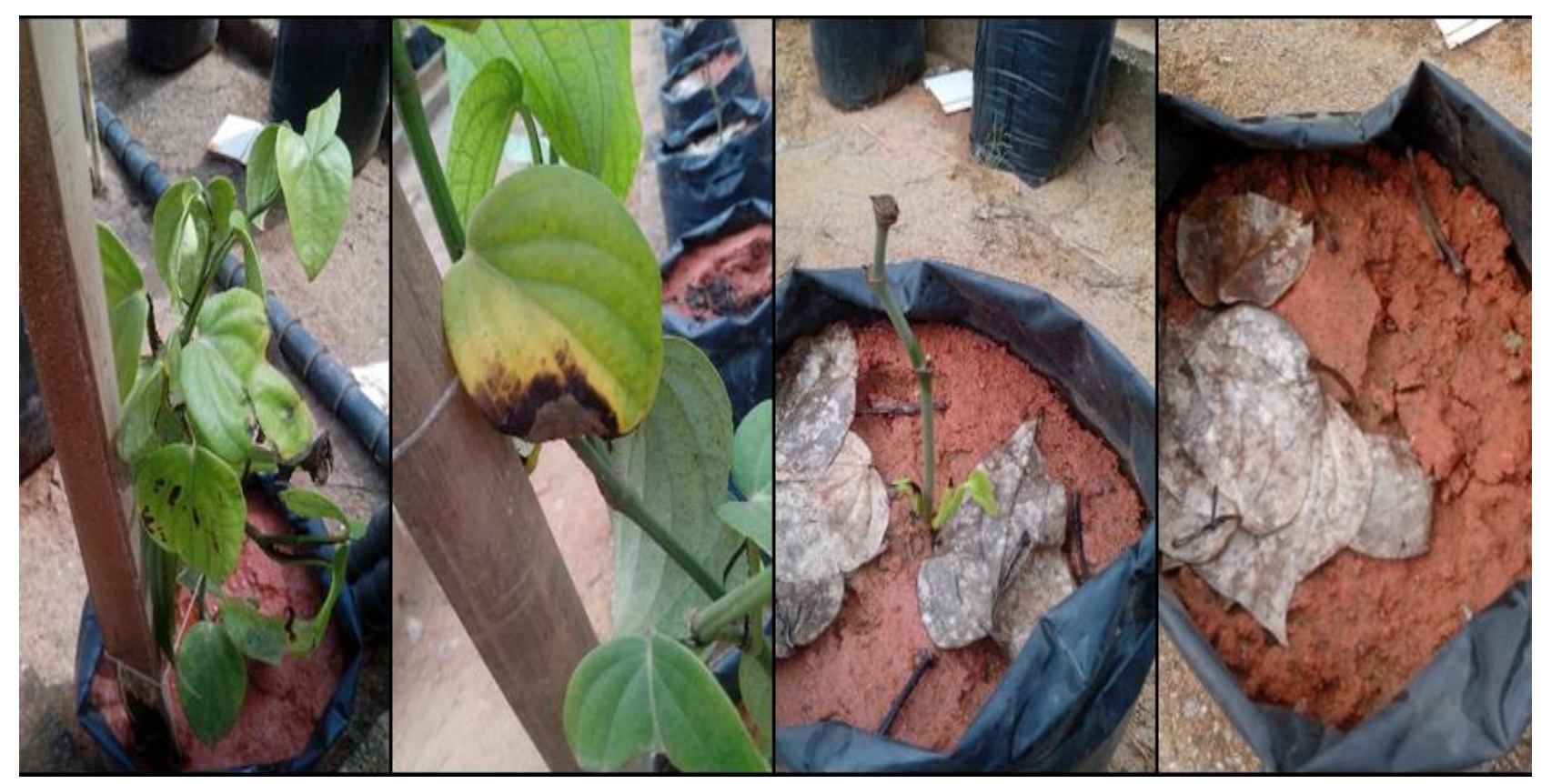

Figure 1 - Phytotoxicity by application of tannery sludge in black pepper cultivar 'Bragantina'.

Tudeia (2016) observed similar symptoms in the production of 'Cravo' lemon seedlings, with an increase in boron and chromium content in the shoots as a function of increasing tannery sludge doses in the substrate. At 45 days after planting, the tannery sludge dose of $50 \%$ increased boron content by $506 \mathrm{mg} \mathrm{kg}^{-1}$ and chromium content by $12.05 \mathrm{mg} \mathrm{kg}^{-1}$.

Banana genotypes under treatment with $100 \mathrm{mM}$ sodium chloride $(\mathrm{NaCl})$ also showed similar phytotoxicity symptoms (Willadino et al., 2011).

In the present study, the treatments without addition of tannery sludge increased the number of leaves over time. For this variable, soil application of $2 \mathrm{mg} \mathrm{dm}^{-3}$ boric acid showed the best results (Table 1 ).

Similarly, passion fruit seedlings developed better with the use of approximately $0.5 \mathrm{mg} \mathrm{dm}^{-3}$ boron; however, doses above and below this value decreased plant development (Prado et al., 2006).
Some plants of the treatment with $0.125 \mathrm{dm}^{3} \mathrm{dm}^{-3}$ tannery sludge started to emit leaves from the tenth sampling (when the boric acid dose was zero grams per plant) and from the last sampling (when the boric acid dose was $4 \mathrm{mg} \mathrm{dm}^{-3}$ ). This may be due to the leaching of elements, mainly sodium. Studies addressing the leaching of nutrients and heavy metals from sewage biosolids in an Oxisol, at a water depth of $23.3 \mathrm{~mm}$ per day, show that sodium leaching corresponded to $196 \mathrm{mg} \mathrm{L}^{-1}$ after 44 days (Campos, 2017).

Regarding stem thickness, plants under the application of 0.125 and $0.250 \mathrm{dm}^{3} \mathrm{dm}^{-3}$ tannery sludge showed stem withering over time (Table 2). Absence of boron application led to less toxicity. Notwithstanding, the plants slightly recovered when applying the boric acid dose of $4 \mathrm{mg} \mathrm{dm}^{-3}$ in association with the tannery sludge dose of $0.125 \mathrm{dm}^{3} \mathrm{dm}^{-3}$. For stem thickness, the treatments without application of tannery sludge did not differ in relation to boric acid doses (Table 2). 
Table 1 - Effect of application of tannery sludge and boron doses on the number of leaves of black pepper, cultivar 'Bragantina'.

\begin{tabular}{|c|c|c|c|c|c|c|c|c|c|c|c|c|c|}
\hline \multirow{3}{*}{ Collect } & \multirow{2}{*}{\multicolumn{4}{|c|}{$\begin{array}{l}\text { Tannery sludge } \\
\left.--0 \mathrm{dm}^{3} \mathrm{dm}^{-3}-\mathrm{dm}^{-3}\right)\end{array}$}} & \multirow{2}{*}{\multicolumn{4}{|c|}{\begin{tabular}{c} 
Tannery sludge \\
\hdashline$--0.125 \mathrm{dm}^{3} \mathrm{dm}^{-3}$ \\
Boric acid $\left(\mathrm{mg} \mathrm{dm}^{-3}\right)$
\end{tabular}}} & \multicolumn{4}{|c|}{ Tannery sludge } & \multirow[t]{3}{*}{ Mean } \\
\hline & & & & & & & & & & oric ac & (mg & $\left.\mathrm{m}^{-3}\right)$ & \\
\hline & 0 & 2 & 4 & Mean & 0 & 2 & 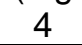 & Mean & 0 & 2 & 4 & Mean & \\
\hline 1 & 5.75 & 7.00 & 6.75 & 8 & .75 & 5.50 & 7.00 & $6.08 \mathrm{a}$ & .00 & 6.25 & 6.75 & $6.33 \mathrm{a}$ & 31 \\
\hline 2 & & 7.0 & 6 & & & & 6.25 & & 75 & 4.7 & .75 & & 36 \\
\hline 3 & & 7.2 & & & & & 5.50 & & & 3. & .00 & & .97 \\
\hline 4 & & & & & & & & & & & & & .33 \\
\hline 5 & & & & & & & & & & 1. & & & 3.8 \\
\hline 6 & & 10 & & & & 1. & 1.75 & & 2.00 & 0. & 0.25 & & 3.7 \\
\hline 7 & & & & & & & & & & & & & 3.94 \\
\hline 8 & & & & & & & 0.00 & 0. & j & 0. & 10 & $\mathrm{~cd}$ & .3 \\
\hline 9 & & 17.00 & 14.25 & & & 0.00 & 0.0 & $0.00 \mathrm{~d}$ & .00 & 0.0 & 0.00 & & 4.8 \\
\hline 10 & & 21.75 & & & & & 0.00 & $0.08 d$ & .00 & 0. & 0.00 & & 6.35 \\
\hline & & & & & & & 0. & & & & & & 7.03 \\
\hline 1 & & & & & & & 0. & $0 ?$ & 0 & 0. & 0.00 & & 7.53 \\
\hline 13 & 75 & 25.50 & 23.00 & 23.4 & 1.00 & 0.00 & 0.00 & $0.33 \mathrm{~d}$ & 0.00 & 0. & 0.00 & $0.00 \mathrm{~d}$ & 7.92 \\
\hline 17 & & 25.75 & 25.00 & 24. & 1.25 & 0.00 & 0.50 & $0.58 \mathrm{~cd}$ & 0.00 & 0.00 & 0.00 & $0.00 \mathrm{~d}$ & 3.25 \\
\hline ean & $12.05 \mathrm{C}$ & $15.21 \mathrm{~A}$ & $13.75 B$ & 13.67 & 1.89 & 1.38 & & 1.79 & $1.93 \mathrm{~A}$ & $1.36 \mathrm{~A}$ & 1.02 & 1.43 & 5.6 \\
\hline
\end{tabular}

Means followed by the same uppercase letter in the row and lowercase in the column do not differ by Tukey's test at $5 \%$ probability

Table 2 - Effect of application of tannery sludge and boron doses on the stem thickness of black pepper, cultivar 'Bragantina'.

\begin{tabular}{|c|c|c|c|c|c|c|c|c|c|c|c|c|c|}
\hline \multirow{3}{*}{ Collect- } & \multirow{2}{*}{\multicolumn{4}{|c|}{$\begin{array}{l}\text { Tannery sludge } \\
---0 \mathrm{dm}^{3} \mathrm{dm}^{-3}----\end{array}$}} & \multicolumn{4}{|c|}{$\begin{array}{l}\text { Tannery sludge } \\
-0.125 \mathrm{dm}^{3} \mathrm{dm}^{-3}----- \\
\end{array}$} & \multicolumn{4}{|c|}{$\begin{array}{l}\text { Tannery sludge } \\
-0.250 \mathrm{dm}^{3} \mathrm{dm}^{-3}\end{array}$} & \\
\hline & & & & Boric acid $\left(\mathrm{mg} \mathrm{dm}^{-3}\right)$ & \multicolumn{4}{|c|}{ oric acid $\left(\mathrm{mg} \mathrm{dm}^{-3}\right)$} & \multicolumn{4}{|c|}{ Boric acid $\left(\mathrm{mg} \mathrm{dm}^{-3}\right)$} & \\
\hline & 0 & 0 & 4 & 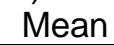 & 0 & 2 & 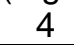 & $\mathrm{Me}$ & 0 & 2 & 4 & Mean & \\
\hline 1 & 506 & 50 & 85 & & & $=0$ & 508 & & 5.42 & 4.73 & .91 & & \\
\hline 2 & & & & & & & & & & & & & \\
\hline 0 & & & & & & & & & & & & & \\
\hline 4 & & & & & & & & & & & & & \\
\hline 5 & & & & & & & & & & 4.93 & & & \\
\hline 6 & & & & & & & & & & 3.84 & & & - \\
\hline 7 & & & & & & & & & & & & & \\
\hline$\varepsilon$ & & & & & & & & & & 2.60 & & & \\
\hline 9 & & 6. & & & & & & 4.3 & & 2.66 & 2.60 & & \\
\hline 10 & & & & & & & & & & 2. & & & \\
\hline & & & & & & & & & & & & & \\
\hline 1 & & & & & & & & & & & & & \\
\hline 13 & 6.14 & 6. & 6. & & 3. & 2.6 & 4. & 3.5 & 4.00 & 1.36 & 1.22 & $2.19 \mathrm{~cd}$ & 3.9 \\
\hline 14 & 6.20 & .45 & 6.35 & $33 \mathrm{a}$ & .73 & 1.20 & 0 & $2.26 \mathrm{~b}$ & 2.95 & 1.40 & 0.00 & $1.45 \mathrm{~d}$ & 3. \\
\hline
\end{tabular}

\begin{tabular}{lllllllllllll}
\hline Mean & 5.76 A & 5.87 A 5.93 A & 5.85 & 4.64 A 3.85 B 4.49 AB & 4.33 & 4.4 A & 3.28 B 3.26 B & 3.64 & 4.61
\end{tabular} Means followed by the same uppercase letter in the row and lowercase in the column do not differ by Tukey's test at $5 \%$ probability

Similarly, Tavanti et al. (2018) found no significant differences in stem diameter in eucalyptus seedlings under boric acid application in the first weeks after planting.

Boric acid doses significantly affected plant height and, similarly, the number of leaves. The treatment with $2 \mathrm{mg} \mathrm{dm}^{-3}$ boric acid and without tannery sludge application allowed the plant to reach a higher height (Table 3). Prado et al. (2006) also showed a similar effect on the vegetative development of passion fruit seedlings under different doses of boron.

The treatments with application of $0.125 \mathrm{dm}^{3} \mathrm{dm}^{-3}$ tannery sludge did not differ from each other, decreasing only plant height over time regardless of the boric acid dose. The treatments with $0.250 \mathrm{dm}^{3} \mathrm{dm}^{-3}$ tannery sludge differed from each other, showing higher toxicity effect with increasing doses of boric acid (Table 3). Reductions in nutrient levels and absorption of toxic elements possibly decreased the yield potential of plants.

In general, chromium and sodium toxicity possibly affected the plants that received tannery sludge. These plants showed total leaf loss, remaining with their stem. However, apex internodes gave way to basal internodes over time (Figure 1). Bean plants grown with tannery sludge withered with increasing doses of this 
treatment, also showing less nitrogen absorption. With

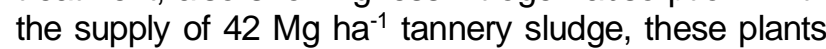

died after 40 days of planting (Prado \& Cunha, 2011).

Table 3 - Effect of application of tannery sludge and boron doses on the height of black pepper $(\mathrm{cm})$, cultivar 'Bragantina'.

\begin{tabular}{|c|c|c|c|c|c|c|c|c|c|c|c|c|c|}
\hline \multirow{3}{*}{ Collect } & \multicolumn{4}{|c|}{$\begin{array}{l}\text { Tannery sludge } \\
---0 \mathrm{dm}^{3} \mathrm{dm}^{-3} \text {----- }\end{array}$} & \multicolumn{4}{|c|}{$\begin{array}{l}\text { Tannery sludge } \\
0.125 \mathrm{dm}^{3} \mathrm{dm}^{-3}\end{array}$} & \multicolumn{4}{|c|}{$\begin{array}{l}\text { Tannery sludge } \\
0.250 \mathrm{dm}^{3} \mathrm{dm}^{-3}\end{array}$} & \multirow{3}{*}{ le } \\
\hline & \multicolumn{4}{|c|}{ Boric acid $\left(\mathrm{mg} \mathrm{dm}^{-3}\right)$} & \multicolumn{4}{|c|}{ Boric acid $\left(\mathrm{mg} \mathrm{dm}^{-3}\right)$} & \multicolumn{4}{|c|}{ Boric acid $\left(\mathrm{mg} \mathrm{dm}^{-3}\right)$} & \\
\hline & 0 & 2 & 4 & Mean & 0 & 2 & 4 & Mean & 0 & 2 & 4 & Mean & \\
\hline 1 & 25.75 & 32.25 & 26.25 & $28.08 \mathrm{f}$ & 29.00 & 28.50 & 29.25 & $28.92 \mathrm{a}$ & 28.50 & 31.25 & 28.25 & $29.33 \mathrm{a}$ & 29.33 \\
\hline 2 & 27.50 & 33.25 & 28.50 & $29.75 \mathrm{f}$ & 30.00 & 29.00 & 30.75 & $29.92 \mathrm{a}$ & 29.75 & 30.75 & 28.00 & $29.5 \mathrm{a}$ & 29.50 \\
\hline 3 & 27.75 & 34.50 & 29.75 & 30.67 ef & 30.00 & 27.50 & 30.75 & $29.42 \mathrm{a}$ & 28.00 & 30.00 & 25.75 & $27.92 a b$ & 27.92 \\
\hline 4 & 27.25 & 36.75 & 30.50 & $.5 \mathrm{ef}$ & 28.50 & 26.25 & 29.00 & $27.92 \mathrm{a}$ & 26.75 & 25.75 & 22.25 & $24.92 a b c$ & 24.92 \\
\hline 5 & 27.25 & 36.50 & 30.00 & 1.25 ef & 28.00 & 23.00 & 28.00 & $26.33 a b$ & 23.75 & 22.50 & 19.75 & $22.00 \mathrm{abcd}$ & 22.00 \\
\hline 6 & 32.50 & 43.25 & 32.50 & 36.08 def & 24.50 & 18.75 & 25.25 & $22.83 a b c$ & 20.75 & 17.25 & 15.75 & 17.92 abcde & 17.92 \\
\hline 7 & 36.75 & 47.50 & 35.25 & $39.83 \mathrm{cdef}$ & 21.00 & 17.75 & 23.25 & $20.67 \mathrm{abcd}$ & 20.00 & 14.75 & 10.00 & 14.92 bcdef & 14.92 \\
\hline 8 & 37.00 & 48.25 & 38.00 & 41.08 bcdef & 20.50 & 15.50 & 20.50 & 18.83 abcde & 18.00 & 12.25 & 9.00 & $13.08 \mathrm{cdef}$ & 13.08 \\
\hline 9 & 39.25 & 51.50 & 42.50 & $44.42 \mathrm{abcde}$ & 17.25 & 14.00 & 17.50 & $16.25 \mathrm{abcde}$ & 18.00 & 8.50 & 8.25 & $11.58 \mathrm{cdef}$ & 11.58 \\
\hline 10 & 42.75 & 54.00 & 48.50 & 48.42abcd & 12.25 & 12.00 & 14.75 & $13.00 \mathrm{bcde}$ & 14.00 & 6.25 & 6.00 & 8.75 def & 8.75 \\
\hline 11 & 44.00 & 53.50 & 52.25 & $49.92 \mathrm{abcd}$ & 12.50 & 6.00 & 13.25 & $10.58 \mathrm{cde}$ & 11.25 & 5.00 & 2.25 & $6.17 \mathrm{ef}$ & 6.17 \\
\hline 12 & 46.00 & 55.50 & 55.25 & $52.25 \mathrm{abc}$ & 10.75 & 6.00 & 9.50 & 8.75 & 10.25 & 3.25 & 2.50 & 5.33 ef & 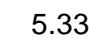 \\
\hline 13 & 48.00 & 59.00 & 58.00 & $55.00 \mathrm{ab}$ & 11.00 & 4.75 & 9.50 & $8.42 \mathrm{de}$ & 9.50 & 3.25 & 1.75 & 4.83 ef & -1.00 \\
\hline 14 & 48.50 & 61.75 & 61.50 & $57.25 \mathrm{a}$ & 7.75 & 2.75 & 6.25 & $5.58 \mathrm{e}$ & 6.25 & 2.50 & 0.00 & $2.92 \mathrm{f}$ & 2.92 \\
\hline ean & $36.45 \mathrm{~B}$ & $46.25 \mathrm{~A}$ & $40.63 \mathrm{~B}$ & 41.11 & $20.21 \mathrm{~A}$ & 6.55 & $0.54 \mathrm{~A}$ & 9.10 & 18.91 & 5.23 & 2.8 & 15.65 & 25.29 \\
\hline
\end{tabular}

The tannery sludge doses contributed to the increase in soil $\mathrm{pH}$; the highest sludge dose led to the highest pH value (Table 4). Similarly, Tudeia (2016) also found higher $\mathrm{pH}$ values as a function of increasing percentages of tannery sludge in the substrate. In turn, boric acid doses did not influence $\mathrm{pH}$ values, which varied between 5.5 and 7.5 in the treatments without the addition of sludge.
Table 5 shows the averages of shoot development variables as a function of boric acid doses at 120 days after transplanting, as well as the levels of boron in the stem and leaves. Regarding shoot development variables, number of leaves (NL), stem thickness (ST), plant height $(\mathrm{H})$, leaf dry matter (LDM), and stem dry matter (SDM) did not differ significantly.

Table 4 - Values of soil pH as function of application of tannery sludge and boron doses.

\begin{tabular}{|c|c|c|c|c|c|c|c|c|c|c|c|}
\hline \multicolumn{4}{|c|}{$\begin{array}{l}\text { Tannery sludge } \\
--0 \mathrm{dm}^{3} \mathrm{dm}^{-3} \text {------ }\end{array}$} & \multicolumn{4}{|c|}{$\begin{array}{l}\text { Tannery sludge } \\
-0.125 \mathrm{dm}^{3} \mathrm{dm}^{-3} \text {------- }\end{array}$} & \multicolumn{4}{|c|}{$\begin{array}{l}\text { Tannery sludge } \\
0.250 \mathrm{dm}^{3} \mathrm{dm}^{-3} \\
-------\end{array}$} \\
\hline \multicolumn{4}{|c|}{ Boric acid $\left(\mathrm{mg} \mathrm{dm}^{-3}\right)$} & \multicolumn{4}{|c|}{ Boric acid $\left(\mathrm{mg} \mathrm{dm}^{-3}\right)$} & \multicolumn{4}{|c|}{ Boric acid $\left(\mathrm{mg} \mathrm{dm}^{-3}\right)$} \\
\hline 0 & 2 & 4 & Mean & 0 & 2 & 4 & Mean & 0 & 2 & 4 & Mean \\
\hline $3 c$ & $44 \mathrm{c}$ & $6.25 c$ & $6.30 \mathrm{C}$ & $7.35 b$ & $7.71 \mathrm{~b}$ & $0 \mathrm{~b}$ & $7.69 \mathrm{~B}$ & $8.15 \mathrm{a}$ & 8.20 & $8.28 \mathrm{a}$ & 8.21 \\
\hline
\end{tabular}

Means followed by the same uppercase or lowercase letter do not differ by Tukey's test at $5 \%$ probability

Leaf boron content also did not differ between boric acid doses (Table 5). In turn, the element accumulated significantly in the stem, with higher values as the boric acid dose increased. Soil application of differ- ent doses of boron in the form of boric acid $\left(\mathrm{H}_{3} \mathrm{BO}_{3}\right)$ positively influenced the levels of this micronutrient in the stem and leaves of eucalyptus (Tavanti et al., 2018). 
Table 5 - Effect of the application of boric acid doses on number of leaves (NL), stem thickness (ST), plant height $(H)$, leaf dry mass (LDM), stem dry mass (SDM), B foliar content (B) and B content in the stem (BS) of black pepper, cultivar 'Bragantina'.

\begin{tabular}{lrrr}
\hline \multirow{2}{*}{ Parameters } & \multicolumn{3}{c}{ Boric acid $\left(\mathrm{mg} \mathrm{dm}^{-3}\right)$} \\
\cline { 2 - 4 } NL & 0 & 2 & \multicolumn{1}{c}{4} \\
ST $(\mathrm{mm})$ & $21.75 \mathrm{a}$ & $25.75 \mathrm{a}$ & $25.00 \mathrm{a}$ \\
$\mathrm{H}(\mathrm{cm})$ & $6.20 \mathrm{a}$ & $6.45 \mathrm{a}$ & $6.35 \mathrm{a}$ \\
LDM $(\mathrm{g})$ & $48.50 \mathrm{a}$ & $61.75 \mathrm{a}$ & $61.50 \mathrm{a}$ \\
SDM $(\mathrm{g})$ & $6.67 \mathrm{a}$ & $8.21 \mathrm{a}$ & $7.80 \mathrm{a}$ \\
B $\left(\mathrm{mg} \mathrm{kg}^{-1}\right)$ & $4.00 \mathrm{a}$ & $5.56 \mathrm{a}$ & $5.20 \mathrm{a}$ \\
BS $\left(\mathrm{mg} \mathrm{kg}^{-1}\right)$ & $19.13 \mathrm{a}$ & $20.00 \mathrm{a}$ & $20.73 \mathrm{a}$ \\
\hline
\end{tabular}

Means followed by the same letter in the row do not differ by Tukey's test at $5 \%$ probability

\section{Conclusion}

Soil application of boric acid affected the early development of black pepper.

Increasing the boric acid dose up to $4 \mathrm{mg}$ $\mathrm{dm}^{-3}$ did not cause a toxic effect on plants, with the dose of $2 \mathrm{mg} \mathrm{dm}^{-3}$ boric acid being the most suitable for the development of the crop.

The authors do not recommend the application of tannery sludge at doses above $0.125 \mathrm{dm}^{3} \mathrm{dm}^{-3}$ for the cultivation of black pepper since it led to plant death in the present study.

\section{Acknowledgements}

The authors thank the Federal Institute of Espírito Santo - Itapina Campus for supporting this research, and the Espírito Santo Research Support Foundation (FAPES) for funding this project.

\section{References}

Botelho SM, Oliveira RF (2009) Fertilidade do solo e nutrição da pimenteira-do-reino. Embrapa Amazônia Oriental (CPATU). Nota técnica. Disponível em: https://www.alice.cnptia.embrapa.br/alice/bitstream/ doc/660455/1/FertilidadeNutricao.pdf (Acesso em: 16 Maio 2020).

Camacho-Cristóbal J, María B, Beato V, Rexach J, Navarro-Gochicoa M, Maldonado J, GonzálezFontes, A (2008) The expression of several cell wallrelated genes in Arabidopsis roots is down-regulated under boron deficiency. Environmental and Experimental Botany. 63: 351-358. doi: 10.1016/j.envexpbot.2007.12.004.

Campos TO (2017) Lixiviação de metais pesados e macronutrientes em solos condicionados com biossólido de lodo de esgoto. UFRRJ (Dissertação de Mestrado em Ciências Ambientais e Florestais).

Comério MSS, Berilli, SS, Lima CF, Pinho LGR, Pereira LC, Pinheiro APB, Berilli APCG, Oliveira EC, Araújo FO (2019) Efeito da adubação foliar com lodo de curtume na brotação de secções de caule de abacaxizeiro para produção de mudas. Revista lfes Ciência 5:170-179. doi: 10.36524/ric.v5i1.276
Dechen AR, Nachtigall GR (2007) Elementos requeridos à nutrição de plantas. In: Novais R.F, Alvarez VVH, Barros NF, Fontes RLF, Cantarutti RBE, Neves JCL (Eds.) Fertilidade do solo, 1rd edn. Sociedade Brasileira de Ciência do Solo. p.91-132.

Embrapa - Empresa Brasileira de Pesquisa Agropecuária (1997) Manual de métodos de análises de solo. 2. ed. Ministério da Agricultura e do Abastecimento, Rio de Janeiro, 212p.

Gianello C, Domaszak SC, Bortolon L, Kray CH, Martins V (2011) Viabilidade do uso de resíduos da agroindústria coureiro-calçadista no solo. Ciência Rural 41(2): 242-245. doi: 10.1590/S010384782011005000007

IBGE (2018) Instituto Brasileiro de Geografia e Estatística - IBGE. Produção Agrícola Municipal. Disponível em: < http://www.sidra.ibge.gov.br > (Acesso em: 25 jun. 2018).

Malavolta E, Vitti, GC, Oliveira, SA (1997) Avaliação do estado nutricional das plantas. 2. ed. Potafos, 319P.

Maistre JLP (1969) Las pimientos. In: Maistre J. Las plantas de especias. Barcelona: Ed. Blume, 123-208.

MAPA (2013) Ministério da Agricultura Pesca e Abastecimento. Secretaria de Defesa Agropecuária. Manual de métodos analíticos oficiais para fertilizantes e corretivos. Brasília, DF: Ministério da Agricultura Pesca e Abastecimento, 2013. Disponível em:https://www.gov.br/agricultura/pt-br/assuntos/ laboratorios/legislacoes-e-metodos/fertilizantessubstratos/manual-de-metodos. Acesso em: 16 Ago. 2020.

Prado AK, Cunha MET (2011) Efeito da Aplicação de Lodo de Esgoto e Curtume nas Características Físico-Químicas do Solo e na Absorção de Nitrogênio por Feijoeiro (Phaseolus vulgaris L.). Revista de Ciências Exatas e Tecnologia, Londrina, 10 (1): 37-41 . 
Prado RM, Natale W, Rozane DE (2006) Níveis críticos de boro no solo e na planta para cultivo de mudas de maracujazeiro-amarelo. Revista Brasileira de Fruticultura, 28(2): 305-309. doi: 10.1590/s010029452006000200034

Sales RA de, Rossini FP, Berilli SS, Galvão ER, Mendes TP, Berilli APCG, Salles RA, Sales RA, Waylson ZQ, Freitas SJ (2018) Foliar Fertilization Using Liquid Tannery Sludge in Conilon Coffee Seedlings Production. Journal of Experimental Agriculture International 22, p. 1-8. doi: 10.9734/JEAI/2018/40201

Silva JDC, Leal TTB, Araújo ASF, Araujo RM, Gomes RLF, Melo W J, Singh RP (2010) Effect of different tannery sludge compost amendment rates on growth, biomass accumulation and yield responses of Capsicum plants. Waste Management 30(10):1976-1980. doi: 10.1016/j.wasman.2010.03.011.

Singh R P, Sarkar A, Sengupta C, Singh, P, Miranda ARL, Nunes LAPL, Araujo ASF, Melo WJ (2015) Effect of utilization of organic waste as agricultural amendment on soil microbial biomass. Annual Research \& Review in Biology 7(3): 155-162. doi: 10.9734/ARRB/2015/11040.
Taiz L, Zeiger E (2004) Fisiologia vegetal. 3.ed. Porto Alegre: Artmed. 722p.

Tavanti RFR, Carvalho JB, Troleis MJB, Bellote JLM, Sena KN, Teixeira Filho MCM (2018) Eficiência da adubação boratada no desenvolvimento de mudas de eucalipto. Revista de Ciências Agrárias 61 (7):1-7. doi: 10.22491/rca.2018.2862

Tedesco MJ, Gianello C, Bissani CA, Bohnen $\mathrm{H}$, Volkweiss SJ (1995) Análise de solo, plantas e outros materiais. 2.ed. UFRGS, $215 p$.

Tudeia TN (2016) Lodo de curtume como alternativa na produção de mudas do porta-enxerto limoeiro 'cravo'. UENF (Dissertação de Mestrado em Produção Vegetal).

Raij BV, Andrade JC, Cantarella H, Quaggio JÁ (2001) Análise química para avaliação da fertilidade de solos tropicais. Campinas: Instituto Agronômico de Campinas, $285 \mathrm{p}$.

Willadino L, Gomes EWF, Silva EFF, Martins LSS, Camara TR (2011) Efeito do estresse salino em genótipos tetraplóides de bananeira. Revista Brasileira de Engenharia Agrícola e Ambiental 15 (1): 53-59. doi:10.1590/s1415-43662011000100008. 